原著

\title{
精神科勤務の看護者のバーンアウトと 医療事故の因果関係についての検討
}

\author{
Causal Relationship of Burnout to Medical Accident among Psychiatric Nurses
}

\section{北岡(東口)和代}

Kazuyo Kitaoka-Higashiguchi

キーワード : バーンアウト, 医療事故, 精神科看護者

Key words : burnout, medical accident, psychiatric nurse

\begin{abstract}
The present study investigated the causal relationship of burnout to medical accident among psychiatric nurses. The subjects were 1,684 nurses working at 16 psychiatric hospitals. The self-administered survey was carried out with 1,295 effective data obtained. The data was obtained using the Japanese research version of the Maslach Burnout Inventory-General Survey, the Nursing Job Stressor Scale, the General Coping Questionnaire, and a medical accident questionnaire. Lastly, casual model was constructed showing the correlation among job stressors, individual styles of coping, burnout, and medical accidents.

Results were as follows: Work overload and interpersonal conflict with patients leads to exhaustion, the first step of the burnout development. Exhaustion subsequently leads to cynicism, the second step of the developmental burnout. Those nurses who have difficulty dealing with patients are more likely to be cynical, callous and indifferent toward patients. Those nurses who have an interpersonal conflict with supervisors or co-workers are also prone to have cynical attitudes. Burnout can consequently lead to medical accidents. Finally, it was found that nurses with an emotion-expression coping style are more likely to experience burnout and to cause accidents.
\end{abstract}

\section{要旨}

本研究は，精神科勤務の看護者のバーンアウトと医療事故との因果関係を検討したものである．精神 科を主とする 16 病院に勤務する全看護者 1,684 名を対象に自己記入式質問紙調查を行い，1,295 名の 有効デー夕を得た。デー夕収集は研究用日本版 Maslach Burnout Inventory-General Survey，臨床看 護職者の仕事ストレッサー測定尺度, General Coping Questionnaire特性版，医療事故饵関する質問 紙を用いて行った。最終的に仕事ストレッサー，コーピングスタイル，バーンアウトと医療事故との関 係を示した因果関係モデルが構築され，次のことが示唆された。仕事量の多さや患者との関係に由来す る負担感や葛藤が続くと, バーンアウトの最初の現象である疲弊感が生じる，この疲弊感は，シニシズ ム的態度というバーンアウトの次の現象を生む。患者に対する冷淡で無関心な態度は患者関係にうまく 
対応できない看護者で特にみられるが，職場の上司や同僚関係に悩んでいる看護者もそのような態度に 楩りやすくなると考えられた。看護者のこのようなバーンアウト状態が医療事故発生を導く。特に感情 表出型のコーピングスタイルをとる看護者はバーンアウトに陥りやすく，医療事故発生に繋がりやすい 集団と考えられた。

\section{I 。緒訔}

バーンアウトには 3 つの現象(疲弊感，シニシズム， 職務効力感の低下)があるとされている(Maslach et al., 2001). そのうち, シニシズムとは仕事に対する 熱意や興味を失い心理的に距離をおく無関心な態度の ことである. 対人サービス職に従事する者はクライエ ントを 1 人の人間として尊㛜をもって対応することが 求められている. また問題解決のためにクライエント と深い繋がりを築く必要がある.しかしながらこうし た職業にある人々がクライエントに対してシニシズム 的な態度をとるようになるのがバーンアウトである.

バーンアウトのアウトカムとして，組織へのコミッ トメントが低下したり，離職・休職などという代償が 支払われることになる (Maslach et al., 2001). 現在 医療現場で深刻な問題になっている医療事故の発生も バーンアウトのアウトカムの 1 つと考えられる. 近年 になり，医療事故と医療従事者のバーンアウトのよう な心理社会的ストレス反応との関係を検討した研究 (川口ら, 2004 ; 小田切ら，2004）がされるようになっ ているが，その因果関係にまで論点を発展させている 研究はみられない.

そこで本研究において, 職場における仕事ストレッ サーや個人がもつコーピングスタイルを含めて, 看護者 のバーンアウトと医療事故との因果関係を検討する.

\section{1. 仮説の設定}

バーンアウト研究の中心的存在である Maslach と 共同研究者である Leiter らはバーンアウト・プロセ スモデルを構築し (Leiter et al., 1988), 修正を図りつ つ(Leiter, 1991，1993), 最終的なモデルを MBI マ ニュアルに紹介している(Maslach et al., 1996). Maslach らが提唱するバーンアウト・プロセスモデ ルと著者らが日本の看護者集団を対象に行ったバーン アウト研究の結果等を根拠に, 本研究における仮説を 設定する.

バーンアウト・プロセスモデルは, ストレス理論で ある Conservation of Resources(COR) 理論 (Hob- foll, 1988, 1989 ; Hobfoll et al., 1993)を適用して構 築されたものである. COR 理論とは人はその人にと って価値あるもの (resources，以下リソースとする) を得たり, 維持しょうとしたりするために努力してい る.このリソースが失われたり脅かされたり，あるい はリソースが要求 (demand) されるものと合わなかっ たり，または期待したほどに報われなかった時に，バ ーンアウトのような否定的な結果を引き起こすとする 考え方である. Maslachらはこの COR 理論を適用 し, 次に述べるバーンアウト・プロセスモデルを構築 している．仕事の量的負荷や対人葛藤などの要求ある いはコーピング能力やソーシャルサポートなどのリソ ースの不足が疲弊感を生じ, 次にシニシズムとなっ て，バーンアウトに陥る．その結果，組織へのコミッ トメントの低下や離職・休職などが起こると考えるモ デルである，ただし，Maslachらの最終モデルには バーンアウトの下位概念である職務効力感と他の変数 との関係は明瞭に示されていない.したがって, 職務 効力感と他の変数との関係を述べる仮説は本研究にお いても設定しないこととする。

また，Leiter(1993) は上司や同僚からのソーシャル サポート不足, つまりリソースの不足はシニシズムと も直接的な関係があると考えている，著者(KitaokaHigashiguchi，2005)が行った一般病院勤務の看護者 を対象とした研究においても同様の結果を得ている. したがってこの考え方を仮説に取り込むこととする.

著者ら (Kitaoka-Higashiguchi et al., 2003 a)は一 般病院勤務の看護者を対象に調査を行い，バーンアウ トを予測する要因を検討した。その結果，仕事の質的 負担と量的負担，職場の人的環境，患者との人間関係 がバーンアウト予測要因であることが示唆された。こ れらは要求，あるいはリソースの不足に相当する要因 であり，本研究における仕事ストレッサーとして仮説 を設定することとする。

Maslach らのモデルでは個人のコーピング能力は リソースの 1 つと考えられており，バーンアウトと直 接的な関係が示されている.著者ら (Kitaoka-Higashiguchi et al., 2003 b) はコーピングスタイル，仕事ス 
トレッサー, ソーシャルサポートとうつ状態との関係 を検討した。その結果, Cooper ら(1988), Deary ら (1996), Revicki ら (1985)によるストレスモデルと同 様，コーピングスタイルは因果関係先行条件として位 置づけることができ，ストレス反応のみならず仕事ス トレッサーとの直接的な関係を認めた。特に，情動焦 点型のコーピングスタイルとして Endler ら (1990)が 命名した emotion-oriented coping(情緒優先対処ス タイル ; 古川ら (1993)の翻訳による)をとる個人は職 場に抢ける仕事量の多さや忙しさなどの要求をより強 く感じ，逆に裁量権などのリソースに対しては否定的 となり，結果としてうつ状態に陥りやすいと考えられ た。したがって，情動焦点型とされるコーピングスタ イルを本研究の仮説に取り入れることとする．ただ し, 先行研究 (Kitaoka-Higashiguchi et al., 2003 b) で採用した Endler ら (1990)の Coping Inventory for Stressful Situations(CISS)の情緒優先対処スタイル を尋ねる項目の中には，不安・抑うつ・緊張などのス トレス反応と交絡した項目が混在していることが指摘 されている(佐々木ら，2002；Stanton et al., 1994). そのため, これらの問題点を解決して開発された尺度 （佐々木ら，2002）を用いて情動焦点型のコーピングス タイルとして佐々木らが命名した「感情表出コーピン グスタイル」を測定する.

以上に述べたことから，仮説を示す。

仮説 1 バーンアウトは疲弊感からシニシズムへと進 む。

仮説 2 感情表出コーピングスタイルから仕事ストレ ッサー(仕事の質的負担，量的負担，職場の 人的環境，患者との人間関係)へとすべて関 係がある。

仮説 3 感情表出コーピングスタイルからストレス反 応である疲弊感へと直接的な関係がある。

仮説 4 仕事ストレッサー(仕事の質的負担，量的負 担，職場の人的環境，患者との人間関係)は すべてバーンアウトの最初の現象としてみら れる疲弊感を生じさせる。

仮説 5 職場の人的環境と患者との人間関係からバー ンアウトの次の現象としてみられるシニシズ ムへと関係がある。

仮説 6 バーンアウトから医療事故が発生する.

\section{2. 用語の操作的定義}

バーンアウト：自己と仕事との関係の中で生じるク
ライシスをいう(Maslach et al., 2001). 疲弊感，シ ニシズム, 職務効力感の低下という 3 つの下位概念を もつ. 疲弊感とは仕事に由来する疲弊感をいい, シニ シズムとは仕事に対する熱意や興味を失い心理的に距 離を扔く無関心な態度のことをいう，看護者では患者 に対する否定的で泠淡な態度をさす。職務効力感の低 下とは仕事に対する自信ややりがいを失うことをい う。これら 3 つの下位概念は, Maslach Burnout Inventory-General Survey (MBI-GS) (Maslach et al., 1996)を用いて測定する.

仕事ストレッサー：臨床現場で働く看護者の仕事ス トレッサーをいう．ただし，職場からの客観的要求で はなく, 個人が認知する主観的要求としてのストレイ ンを意味する。

仕事の質的負担：仕事の複雑さや困難性など仕事の 質に関するストレッサーに由来するストレインをい う。臨床看護職者の仕事ストレッサー測定尺度 (Nursing Job Stressor Scale : NJSS ; 東口ら，1998)を用 いて測定する。

仕事の量的負担：仕事量の多さに関するストレッサ 一に由来するストレインをいう．NJSS を用いて測定 する。

職場の人的環境：職場の上司あるいは同僚からのソ ーシャルサポート不足と看護者間での仕事や看護に対 する考え方の違いというストレッサーに由来するスト レインをいう．NJSSを用いて測定する。

患者との人間関係：患者との人間関係に関するス卜 レッサーに由来するストレインをいうＮNJSS を用い て測定する.

感情表出コーピングスタイル：一般の日常生活にお いて，嫌な出来事や困った出来事に直面した時に個人 がとる特性的なコーピングのうち，その時の気持ちを 表情や態度に表すスタイルをいう。 General Coping Questionnaire (GCQ) 特性版(佐々木ら，2002)を用い て測定する。

医療事故：看護者が起こす配膳間違い(治療食の間 違い，絶食患者に配膳，等)，医療機器操作間違い， チューブ抜去(抜いてしまった，抜けていたのに気が つかなかった，等), 処置・検査間違い(前処置忘れ, 手技ミス，患者間違い，等)，点滴・注射間違い(内 容・量・投与方法等の間違い), 内服薬間違い(内容・ 量・与薬方法等の間違い，患者間違い，等)，転倒， 転落の 8 つをいう. 


\section{II. 研 究 方 法}

\section{1. 研究デザイン}

質問紙法により横断面でのデー夕収集を行い，パス 解析を用いた統計的手法により因果関係仮説を検討す る仮説検証研究である.

\section{2. 調査対象者}

表 1 に示すように, 調査対象病院は精神科を主とす る 16 病院であった. A 県内 12 病院, B 県内 2 病院, $\mathrm{C}$ 県内 1 病院，D 県内 1 病院である。病院の開設者は 法人 13 病院, 公立 2 病院, 個人 1 病院である. 病床 数は 96〜1,368である.

調査対象者は各病院に勤務する全看護者(看護師, 准看護師) とし, 合計 1,685 名であった. 調査票の回 収率は 1 病院(回収率=66.7\%)を除いて，83.0〜 $100.0 \%$ と良好で平均回収率は $90.3 \%$ であった。表 2 に示すように, 各質問紙の無効回答率に調査対象病 院による大きな偏りはなかった。医療事故に関する質 問紙の無効回答率に関しても, 他の質問紙のそれと比 べて特に高くはなかった。したがって, 調査票 1,295 票 (平均有効回答率= $85.2 \%$ )をデー夕分析の対象と した.

\section{3. データ収集(調査方法と調査票の構成)}

調査に協力が得られた病院の看護部を通して部署ご とに自己記入式調查票を配布し，10 日〜 2 週間の留 め置き調查を行った。調査は 2003 年 $7 \sim 9$ 月に実施 した.

調査票の構成は, MBI - GS の翻訳版, NJSS, $\mathrm{GCQ}$ 特性版, 医療事故に関する質問紙, フェイスシ ートからなる。

研究用日本版 MBI-GS：16 項目. 下位尺度：疲弊 感, シニシズム, 職務効力感の 3 因子である. 回答形 式は原版の MBI-GS と同様で，1 年間を目安とした 頻度次元 $\cdot 7$ 件法(年に $2 \sim 3$ 回, 月に 1 回, 週に 1 回など)である. 各項目に対する回答に $0 \sim 6$ 点を付 与し，下位尺度の合計点を項目数で割った值が下位尺 度得点となる，得点が高いほど疲弊感とシニシズムが 強く, 逆に得点が低いほど職務効力感が弱く, バーン アウトの程度が高いと解釈する．信頼性および妥当性 については検証されている (Kitaoka-Higashiguchi et al., 2004; 北岡(東口) ら, 2004 a).

NJSS : 33 項目. 下位尺度：「職場の人的環境」,
表 1 調査対象病院亡調査対象者および調査票の回収数

\begin{tabular}{cccrrr}
\hline 病院 & 所在地 & 開設者 & 病床数 & 看護者数 & \multicolumn{1}{c}{ 回収数(\%) } \\
\hline 1 & A 県 & 公立 & 100 & 46 & $46(100.0)$ \\
2 & A 県 & 法人 & 189 & 42 & $41(97.6)$ \\
3 & A 県 & 法人 & 264 & 67 & $67(100.0)$ \\
4 & A 県 & 法人 & 96 & 20 & $19(95.0)$ \\
5 & A 県 & 法人 & 298 & 75 & $72(96.0)$ \\
6 & A 県 & 法人 & 171 & 51 & $51(100.0)$ \\
7 & A 県 & 法人 & 356 & 106 & $95(89.6)$ \\
8 & A 県 & 個人 & 263 & 80 & $79(98.8)$ \\
9 & A 県 & 法人 & 207 & 77 & $73(94.8)$ \\
10 & A 県 & 法人 & 145 & 48 & $48(100.0)$ \\
11 & A 県 & 法人 & 528 & 162 & $108(66.7)$ \\
12 & A 県 & 法人 & 157 & 63 & $56(88.9)$ \\
13 & B 県 & 法人 & 267 & 105 & $102(97.1)$ \\
14 & B 県 & 法人 & 505 & 199 & $196(98.5)$ \\
15 & C 県 & 公立 & 1.368 & 497 & $428(86.1)$ \\
16 & D 県 & 法人 & 132 & 47 & $39(83.0)$ \\
\hline 合計 & & & 5.046 & 1.685 & $1.520(90.3)$ \\
\hline
\end{tabular}

「看護職者としての役割」,「医師との人間関係と看護 職者としての自律性」，「死との向かい合い」，「仕事の 質的負担」,「仕事の量的負担」，「患者との人間関係」 に関するストレッサーの 7 因子である. 描かれた状況 に対して強さ次元・ 5 件法で回答する. 各項目に対す る回答に $0 \sim 4$ 点を付与し, 下位尺度の合計点を項目 数で割った值が下位尺度得点となる. 得点が高いほ ど，そのストレッサーによるストレインが強いと解釈 する，尺度開発時に，信頼性および妥当性は検証され ている(東口ら，1998)。

GCQ 特性版：32 項目.下位尺度：「感情表出」, 「情緒的サポート希求」,「認知的再解釈」,「問題解決」 の 4 因子である. 各項目 $1 \sim 5$ 点の 5 件法で, 各下位 尺度の得点範囲は $8 \sim 40$ 点である. 尺度開発時に, 信頼性抢よび妥当性は検証されている(佐々木ら, 2002).

医療事故に関する質問紙：杉谷 (2000)が行った看護 上の事故調査によると, 事故発生が多いのは誤配膳, 注射, 転倒, 与薬, 転落, 機器類誤操作, チューブ抜 去, 検査とされている. したがってこれら 8 つ事故 を本研究における医療事故とした。回答者には MBIGS と同様に 1 年間を目安として，そのような事故を 「起こさなかった」,「起こしそうになった」,「起こし た」で尋ねた。

フェイスシート：性，年齢，婚姻状況などの個人属 性と, 職種, 現在の職種の経験年数, 当該病院での勤 務年数, 職位, 勤務形態, 勤務場所などの職業要因を 尋ねた。 
表 2 調査票の無効回答率・有効回答率

\begin{tabular}{|c|c|c|c|c|c|c|}
\hline 病院 & 回収数 (\%) & (1)無効数 (\%) & (ㄹ)無効数 (\%) & (3)無効数 (\%) & (4)無効数 (\%) & 有効数 (\%) \\
\hline 1 & $46(100.0)$ & $2(4.3)$ & $3 \quad(6.5)$ & 1 (2.2) & $0 \quad(0.0)$ & $43(93.5)$ \\
\hline 2 & $41 \quad(97.6)$ & $2 \quad(4.9)$ & $4 \quad(9.8)$ & $0 \quad(0.0)$ & 5(12.2) & $33(80.5)$ \\
\hline 3 & $67(100.0)$ & $2 \quad(3.0)$ & $2 \quad(3.0)$ & $0 \quad(0.0)$ & $5 \quad(7.5)$ & $59(88.1)$ \\
\hline 4 & $19 \quad(95.0)$ & $0 \quad(0.0)$ & 1 (5.3) & l (5.3) & $1 \quad(5.3)$ & $17(89.5)$ \\
\hline 5 & $72 \quad(96.0)$ & 3 (4.2) & $2 \quad(2.8)$ & $1 \quad(1.4)$ & $7 \quad(9.7)$ & $61(84.7)$ \\
\hline 6 & $51(100.0)$ & $1 \quad(2.0)$ & $3 \quad(5.9)$ & $3 \quad(5.9)$ & $7(13.7)$ & $43(84.3)$ \\
\hline 7 & $95 \quad(89.6)$ & $7 \quad(7.4)$ & $1(1.1)$ & $6 \quad(6.3)$ & $15(15.8)$ & $73(76.8)$ \\
\hline 8 & $79 \quad(98.8)$ & $5 \quad(6.3)$ & $1 \quad(1.3)$ & $4 \quad(5.1)$ & $5 \quad(6.3)$ & 71 (89.9) \\
\hline 9 & $73 \quad(94.8)$ & $2 \quad(2.7)$ & $0 \quad(0.0)$ & $0 \quad(0.0)$ & $3(4.1)$ & $69(94.5)$ \\
\hline 10 & $48(100.0)$ & $1 \quad(2.1)$ & $1 \quad(2.1)$ & 2 (4.२) & $5(10.4)$ & 42 (87.5) \\
\hline 11 & $108 \quad(66.7)$ & $7 \quad(6.5)$ & $9 \quad(8.3)$ & $4 \quad(3.7)$ & $7 \quad(6.5)$ & 90 (83.3) \\
\hline 12 & $56 \quad(88.9)$ & $9(16.1)$ & $3 \quad(5.4)$ & 2 (3.6) & 11 (19.6) & 39 (69.6) \\
\hline 13 & $102 \quad(97.1)$ & $14(13.7)$ & $14(13.7)$ & $11(10.8)$ & $10 \quad(9.8)$ & 71 (69.6) \\
\hline 14 & $196 \quad(98.5)$ & $15 \quad(7.7)$ & $7 \quad$ (3.6) & $9 \quad(4.6)$ & $15 \quad(7.7)$ & $159(81.1)$ \\
\hline 15 & $428 \quad(86.1)$ & $9 \quad(2.1)$ & $12 \quad(2.8)$ & $12 \quad(2.8)$ & 21 (4.9) & $391 \quad(91.4)$ \\
\hline 16 & $39 \quad(83.0)$ & $3 \quad(7.7)$ & $3 \quad(7.7)$ & $3(7.7)$ & $3(7.7)$ & 34 (87.2) \\
\hline 合計 & $1.520 \quad(90.3)$ & $82 \quad(5.4)$ & $66 \quad(4.3)$ & 59 (3.9) & $120 \quad(7.9)$ & 1,295 (85.2) \\
\hline
\end{tabular}

\section{4. データ分析}

収集したデー夕から，本研究に必要な観測変数を取 り出して分析を行う。まず，相関分析により研究用日 本版 MBI-GS の疲弊感，シニシズム，職務効力感の 3 変数, NJSS から仕事の質的負担, 量的負担, 職場 の人的環境，患者との人間関係の 4 変数, GCQ 特性 版から感情表出の 1 変数の各変数間の関連性を確認し た後，仮説の検討を行う．仮説の検証は因果関係を確 かめるものなので，パス解析を用いる，仮説を入れ込 んだ因果関係仮説モデルを構築し, SPSS の統計パッ ケージ AMOSを用いて解析を実施した。

\section{5. 倫理的配慮}

本研究は石川県立看護大学倫理委員会の承認を得て いるが，以下に示す点に配慮した。

\section{1）調査対象となる個人の人権の擁護}

調査対象は調查票に添付する「アンケートへのご協 力のお願い」を読んで，自発的に協力してくれる者の みとした。病院の管理者等には調査協力を強制しない ように求め，個人の拒否する権利を保障した。

\section{2）調査の実施によって生じる個人の不利益なら びに危険性に対する配慮}

調査は無記名とし，個人の特定ができないようにし た。また，回答後の調査票は各自が封印した後回収 し，病院の管理者等に情報が漏れないようにした．調 査の実施にあたっては調査対象病院名等の特定情報は
すべて匿名化し，著者以外には漏れないようにした。 また，調査デー夕処理過程においても同様に匿名化に より，外部に漏れないようにした。

\section{3）調査対象となる者の理解と同意}

調査対象病院の管理者等には調査研究計画書に基づ いて詳細な説明を行った。個人には調查票に「アンケ ートへのご協力の打願い」を添付し，調査の主旨等を 伝えた。

\section{III. 結果}

\section{1. 調査対象者の個人属性・職業要因について}

表 3 に, 調査対象者の個人属性(性，年齢，婚姻状 況) と職業要因(職種，現在の職種の経験年数，当該病 院での勤務年数，職位，勤務形態，勤務場所)を示す. 男性が約 3 割，女性が約 7 割であった。年齢は 20 〜 78 歳で，平均年齢は 40.8 (標準偏差：SD =11.6)歳で あった。未婚者が約 3 割，既婚者が約 6 割，死別・離 婚等の者が約 1 割であった．調査対象者は看護師が約 7 割，准看護師が約 3 割であった。経験年数は $1 \sim 60$ 年で，平均経験年数は $15.0(\mathrm{SD}=10.4)$ 年であった。 勤務年数は 1 ～43 年で，平均勤務年数は $9.5(\mathrm{SD}=$ 7.7)年であった。職位についてはスタッフが約 8 割, 管理職が約 2 割であった．勤務形態については過半数 が 3 交代制勤務であったが， 2 交代勤務の者や日勤を 主にしている者がそれぞれ約 2 割いた．外来あるいは デイケア・訪問看護・看護部等に勤務する者が約 1 割 
表 3 調査対象者の個人属性・職業要因

\begin{tabular}{|c|c|c|}
\hline & $n$ & $(\%)$ \\
\hline \multicolumn{3}{|l|}{ 性 } \\
\hline 男性 & 335 & (25.9) \\
\hline 女性 & 958 & (74.0) \\
\hline (欠損值) & ? & $(0.2)$ \\
\hline 合 計 & 1.295 & \\
\hline \multicolumn{3}{|l|}{ 年齢 } \\
\hline 20 代 & 284 & (21.9) \\
\hline 30 代 & 324 & (25.0) \\
\hline 40 代 & 341 & (26.3) \\
\hline 50 代 & 283 & (21.9) \\
\hline 60 代以上 & 59 & $(4.6)$ \\
\hline (欠損值) & 4 & $(0.3)$ \\
\hline 合 計 & 1,295 & \\
\hline \multicolumn{3}{|l|}{ 婚姻状況 } \\
\hline 未婚 & 390 & (30.1) \\
\hline 既婚 & 780 & $(60.2)$ \\
\hline その他(死別, 離婚等) & 121 & $(9.3)$ \\
\hline （欠損值） & 4 & $(0.3)$ \\
\hline 合 計 & 1,295 & \\
\hline \multicolumn{3}{|l|}{ 職種 } \\
\hline 看護師 & 909 & $(70.2)$ \\
\hline 准看護師 & 384 & $(29.7)$ \\
\hline (欠損值) & ? & $(0.2)$ \\
\hline 合 計 & 1,295 & \\
\hline \multicolumn{3}{|l|}{ 経験年数 } \\
\hline 3 年以下 & 185 & $(14.3)$ \\
\hline $4 \sim 9$ 年 & 296 & (22.9) \\
\hline 10 19 年 & 385 & (29.7) \\
\hline உ0〜29 年 & 296 & (22.9) \\
\hline 30 年以上 & 133 & (10.3) \\
\hline 合 計 & 1,295 & \\
\hline \multicolumn{3}{|l|}{ 勤務年数 } \\
\hline 3 年以下 & 325 & $(25.1)$ \\
\hline $4 \sim 9$ 年 & 480 & $(37.1)$ \\
\hline $10 \sim 19$ 年 & 327 & (25.3) \\
\hline 20 年以上 & 163 & (12.6) \\
\hline 合 計 & 1,295 & \\
\hline \multicolumn{3}{|l|}{ 職位 } \\
\hline スタッフ & 1.041 & $(80.4)$ \\
\hline 管理職 & 252 & (19.5) \\
\hline (欠損値) & 2 & (0.2) \\
\hline 合 計 & 1,295 & \\
\hline \multicolumn{3}{|l|}{ 勤務形態 } \\
\hline 日勤のみ & 198 & (15.3) \\
\hline 日勤・当直 & 59 & (4.6) \\
\hline 2 交代制 & 336 & (25.9) \\
\hline 3 交代制 & 700 & $(54.1)$ \\
\hline （欠損値） & 2 & (0.2) \\
\hline 合 計 & 1,295 & \\
\hline \multicolumn{3}{|l|}{ 勤務場所 } \\
\hline 外来 & 40 & (3.1) \\
\hline その他 & 61 & $(4.7)$ \\
\hline 病棟 & 1,194 & (92.2) \\
\hline 合 計 & 1,295 & \\
\hline
\end{tabular}

いたが，病棟勤務者が多く約 9 割であった。

\section{2. 尺度間の相関分析について}

表 4 に, 研究用日本版 MBI-GS の疲弊感, シニシ ズム, 職務効力感, NJSS の仕事の質的負担, 量的負 担，職場の人的環境，患者との人間関係， $\mathrm{GCQ}$ 特性 版の感情表出の 8 つの尺度の平均値, 標準偏差, Cronbach の $\alpha$ 係数，尺度間の相関行列を示す. 各 尺度の因子の $\alpha$ 係数は.70 . 89 でデー夕の信頼性は 確保されていた。

\section{3. 看護上の医療事故について}

表 5 に，1 年間で看護上の医療事故を発生した看護 者の数を示す.最も多かったのは転倒で，看護者の約 6 割が起こしていた，次に多かったのは転落と内服薬 間違いであり，看護者の約 3 割が起こしていた。その 次に多かったのはチューブ抜去であり，看護者の約 2 割が起こしていた。また，配善間違い，処置・検査間 違い，点滴・注射間違いも看護者の約 1 割が起こして いた．医療機器操作間違いが最も少なかった。

\section{4. 医療事故因果関係仮説モデル}

図 1 に，仮説に基づいて描いた因果関係仮説モデル を示す。まず，転倒発生を医療事故とし，仮説モデル に基づいて観測変数を投入したパス解析を実施した。 その結果，適合度指標 GFI が.731, AGFI が. 355 , RMSEA が.281, AICが 1584.456 であり, モデルと データの適合度は不十分と言えた。また，仕事の質的 負担から疲弊感へのパスと職場の人的環境から疲弊感 へのパスの係数值は小さく，ともに有意ではなかっ た. 仕事の質的負担とバーンアウトとの関連は強くな いと考えられたため, この観測変数をモデルから削除 して検討を進めた。また，職場の人的環境と疲弊感と の関連も強くないと考元られたため, 同僚関係から疲 弊感へのパスを削除した。さらに，修正指数およびモ デルの改善度から, 仕事の量的負担, 職場の人的環 境，患者との人間関係の間には相関関係があるとする のが妥当と考えられた。

以上の検討に基づいてモデルを修正し，再度解析を 実施した。その結果，修正したモデルでは適合度指標 が大きく改善され, GFIが.995, AGFIが.984, RMSEA が.036, AICが 61.166 とモデルとデータの 適合度は十分と言えた。

図 2 に，最終モデルを示す．数值は標準化パス係数 
表 4 尺度の平均値, 標準偏差, Cronbach の $\alpha$ 係数, 相関行列

$(n=1,295)$

\begin{tabular}{|c|c|c|c|c|c|c|c|c|c|c|}
\hline & 変数 & MeantSD & $\alpha$ & 2 & 3 & 4 & 5 & 6 & 7 & 8 \\
\hline 1 & 疲弊感 & $3.44 \pm 1.45$ & .89 & .61 & .01 & .33 & .45 & .29 & .32 & .13 \\
\hline 2 & シニシズム & $2.21 \pm 1.41$ & .85 & & -.05 & .26 & .31 & .29 & .33 & .15 \\
\hline 3 & 職務効力感 & 2.23土1.22 & .85 & & & -.12 & .00 & -.03 & -.09 & .03 \\
\hline 4 & 仕事の質的負担 & $2.83 \pm 0.78$ & .78 & & & & .61 & .55 & .45 & .11 \\
\hline 5 & 仕事の量的負担 & $2.84 \pm 0.76$ & .82 & & & & & .52 & .47 & .12 \\
\hline 6 & 職場の人的環境 & $2.64 \pm 0.83$ & .83 & & & & & & .39 & .19 \\
\hline 7 & 患者亡の人間関係 & $2.78 \pm 0.82$ & .70 & & & & & & & .19 \\
\hline 8 & 感情表出コーピング & $21.11 \pm 5.17$ & .89 & & & & & & & \\
\hline
\end{tabular}

表 5 看護上の医療事故発生状況

$(n=1,295)$

\begin{tabular}{|c|c|c|c|}
\hline & 起こさなかった & 起こしそうになった & 起こした \\
\hline & $n \quad(\%)$ & $n \quad(\%)$ & n $(\%)$ \\
\hline 配膳間違い & $912(70.4)$ & 231 (17.8) & $152(11.7)$ \\
\hline 医療機器操作間違い & 1,078 (83.२) & $173(13.4)$ & $44 \quad(3.4)$ \\
\hline チューブ抜去 & $970(74.9)$ & $124 \quad(9.6)$ & 201 (15.5) \\
\hline 処置・検査間違い & $1.053(81.3)$ & 145 (11.?) & $97 \quad(7.5)$ \\
\hline 点滴・注射間違い & $1.074(82.9)$ & $136(10.5)$ & $85 \quad(6.6)$ \\
\hline 内服薬間違い & $639(49.3)$ & 306 (23.6) & $350(27.0)$ \\
\hline 転倒 & 263 (२0.3) & $220(17.0)$ & $812(62.7)$ \\
\hline 転落 & $725(56.0)$ & $204(15.8)$ & $366(28.3)$ \\
\hline
\end{tabular}

值である．感情表出コーピングスタイルから疲弊感へ のパス係数值はやや小さく $\mathrm{p}$ 值が.013であったが, その他のパス係数はいずれも有意水準 $0.1 \%$ 以下であ った.

次に，最終モデルにおいて，医療事故をその他の事 故とした場合を解析した。 パス係数值は転落と点滴・ 注射間違いでは各々. $12(\mathrm{p}<.001)$ ，チューブ抜去で は. $10(\mathrm{p}<.001)$, 医療機器操作間違いと内服薬間違

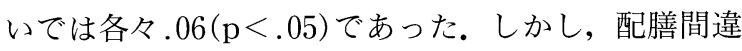
いでは.05 $(\mathrm{p}=.061)$, 処置・検査間違いでは.03 $(\mathrm{p}=.310)$ となり，シニシズムからのパス係数值は有 意ではなかった。

\section{IV. 考察}

\section{1. 仮説について}

疲弊感からシニシズムへのパスは最も大きく, 仮説 1 は支持された。

感情表出コーピングスタイルは仕事ストレッサーで ある仕事の量的負担，職場の人的環境，患者との人間 関係とすべて正の関係があり，仮説 2 は支持された。 また，感情表出コーピングスタイルは疲弊感とも直接 的な関係があり，仮説 3 は支持された。ただし，他の 変数間の関係に比べるとその関係は小さく，個人のコ ーピングスタイルはストレス反応に直接関係する要因
というより，むしろストレッサーの認知の仕方により 大きく関係する要因であることが示唆された.

仮説 4 において仕事ストレッサーのすべてが疲弊感 と関係があるとされたが，最終モデルで関係があった のは仕事の量的負担と患者との人間関係であった。特 に，仕事の量的負担が疲弊感をより生じさせる要因で あることが示唆された. 職場の人的環境と患者との人 間関係はシニシズムに関係しており，仮説 5 は支持さ れた。特に，患者との人間関係がシニシズム的態度と なる要因であることが示唆された．先に述べたよう に, 本研究における仕事ストレッサー(仕事の質的負 担，仕事の量的負担，職場の人的環境，患者との人間 関係) は一般病院に勤務する看護者を対象とした研究 結果(Kitaoka-Higashiguchi et al., 2003 a)を仮説に 取り込んだものである.その結果, 仕事の量的負担と 患者との人間関係がバーンアウトに導くより強い要因 であることが示唆された．著者ら $(2004$ b)が精神科看 護者を対象とした検討に抢いても，仕事の量的負担と 患者との人間関係がバーンアウトに最も強く関連して いることが示唆されている．精神科勤務の看護者は健 康的な対人関係をもつことに困難さを抱えている統合 失調症, 気分障害, 人格障害, アルコール依存症など の人々に看護ケアを提供している。そのため他領域の 看護者に比べて，患者との人間関係に由来する仕事ス トレッサーをより多くもっているものと考えられる. 


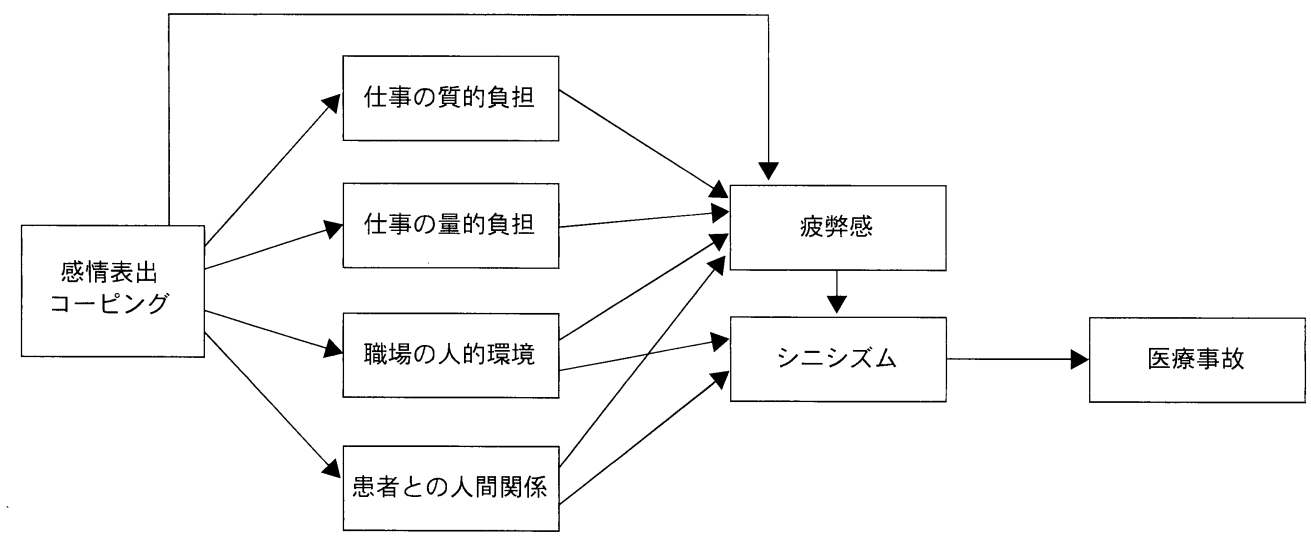

図 1 医療事故因果関係仮説モデル

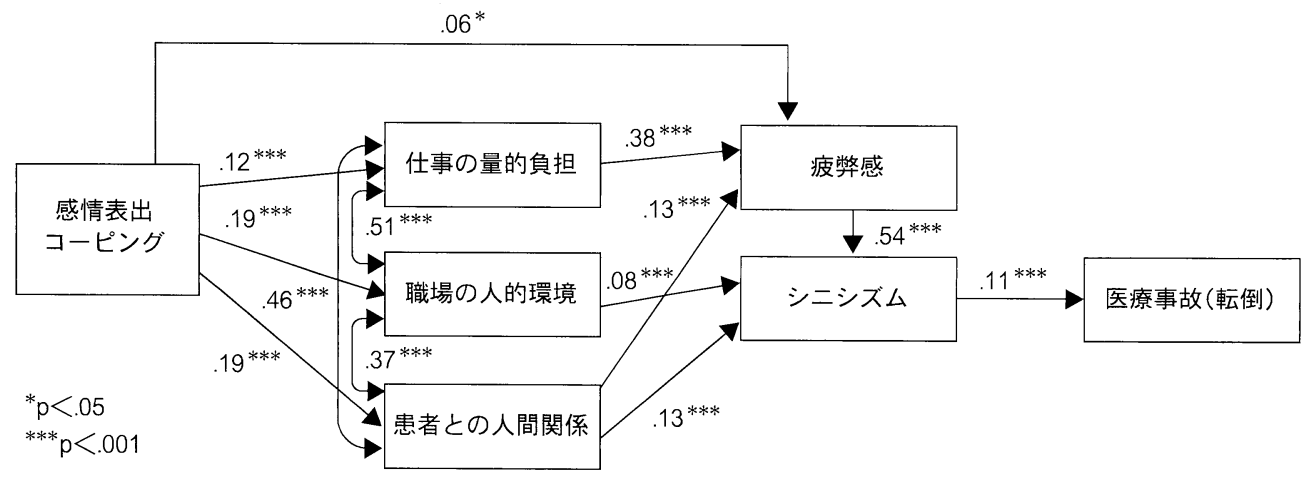

図 2 医療事故因果関係最終モデル

この結果が精神科勤務の看護者の特異性なのかについ ては，今後さらに検討していく必要がある.

シニシズムから医療事故への因果について，有意な パスが認められたのは設定した 8 つ医療事故のう ち, 配膳間違いと処置・検査間違いを除く $6 \supset$ (転倒, 転落, 点滴・注射間違い, チューブ抜去, 医療機器操 作間違い, 内服薬間違い)であった，医療機器操作間 違いと内服薬間違いへのパス值がやや小さかったこと からも，因果関係を述べるには慎重さが求められる が，仮説 6 を支持する結果が得られたと考える.

\section{2. 本研究結果から描かれるバーンアウトから 医療事故発生について}

本研究において示された因果関係モデルを基に，看 護者がバーンアウトから医療事故発生へとたどる状況 を描いてみる。

看護者は「こなさなければならない仕事が多い」, 「仕事を終えるのに十分な時間がない」，「人手が十分 でない」と感じるようなストレスフルな状態で勤務を
続けている. 看護ケアの提供相手である患者との関係 にもさまざまな葛藤を起こしながら働いている，この ような状況下での勤務が続くと, ストレス反応として 疲弊感が生じる. バーンアウトの最初の現象である. 「1日の仕事が終わるとぐったりする」，「1日中働く ことは本当にストレスだ」,「仕事で精力を使い切って しまった」などと感じるようになるのである.この疲 弊感は，仕事量の多さからくる負担感が特に引き金と なる。

この痚弊感に対する自己防衛手段として, 看護者は 仕事に対する熱意や興味を失い，自分と仕事との間に 心理的距離をおくという無関心な態度をとるようにな る. バーンアウトの次の現象である.「仕事のことで いろいろとわずらわされたくない」，「自分がしている 仕事は何かの役に立っているかということはどうでも よい」という態度になるのである。このシニシズム的 態度は患者との関係にうまく対応できず葛藤や負担感 が強い看護者で特にみられるようになり, 患者を人で はなく‘物’のように扱う冷淡さや「患者に何が起ころ 
うと気にしない」という無関心さとなる．また「他のス タッフが協力的でない」，「サポートしてくれる人がい ない」，「相談できる人がいない」など職場の上司や同 僚との人間関係に悩んでいる看護者もそのような態度 に陥りやすくなると考えられる。

看護者のこのようなバーンアウト状態が医療事故発 生を導くことになる．注意すべきは，看護者のなかで も嫌な出来事や困った出来事に直面した時「嫌だ」, 「不快だ」「困った」，「やりきれない」と気持ちを表情 や態度に表す感情表出型の者である，感情表出型の看 護者は職場における上司・同僚関係や患者関係に由来 する葛藤や負担感をより強くもつ傾向があり，また仕 事量の多さに対する負担感もより強くもっていると考 えられる、それらによりバーンアウトに陥りやすく, ひいては医療事故発生に繋がりやすい集団と考えられ る.

\section{3. 看護者が医療事故を発生するメカニズムに ついて}

医療事故はヒューマンエラーの一つと言われてお り，発生原因は大きく分けて，外的原因と内的原因の 2 つに分類することができる(正田，2001).外的原因と して人間関係(Men), 機械(Machine), 媒体(Media), 管理(Management)の $4 \mathrm{M}$ が指摘されている.人間 関係とは職場における同僚，上司，部下などの人間関 係の状態を指す。人間関係が良好でないと，命令・指 示・合図など意思疎通がスムースにいかず，また連携 作業や協働作業におけるティームワークがうまくいか ずエラーが起こりやすくなる．機械とは装置や機器類 が人間の能力や特性に合っていないと, 間違いや不安 全行動が起こりやすくなることを指す，媒体とは人間 と機械の仲立ちをするものを意味する．作業方法，作 業環境条件，休息時間，作業時間の長さ等が含まれ る。これらの条件が至適範囲にあるうちは仕事がしや すいが，限界值を超えると不快感や機能低下を招き， 注意の持続が困難になりエラーが起こりやすくなる. 管理とは安全管理組織, 安全法規の整備, 指示事項の 実施と取り締まり，教育訓練などを指し，それらが不 備だとエラーが発生しやすくなる。

本研究での医療事故因果関係モデルにおいても，上 司や同僚との関係あるいは患者との関係という人間関 係の媒体と言える仕事量の多さが位置づけられてい る.しかし，人間関係や仕事量の多さはストレスモデ ルにおいては，ストレッサーとして扱われる。ストレ
ッサーがストレス反応を生じ，七ューマンエラーとい う結果を導くという考え方である。人間関係や仕事量 の多さがエラーの直接的な原因であるという考えを否 定はできない.しかしながら，本研究の結果からは， それらの要因は‘ヒューマン(看護者)’というブラック ボックスのなかを通ると，患者を人ではなく物’よ うに扱うシニシズム的態度となり，その態度がヒュー マンエラーを導くと考えることができよう。

バーンアウトは看護者自身にとっての心身の健康問 題であると同時に，患者自身にとっても重大な問題と なる，患者に提供される医療・看護ケアレベルの低下 をもたらすからである，本研究では，バーンアウトは 患者の生命を脅かし，多大な被害をもたらす医療事故 発生の原因ともなることが示唆された，看護者をバー ンアウトさせない予防対策を組織的にとることは，医 療事故防止対策としても重要であり，緊急課題である と考える.

\section{4. 本研究における限界}

本研究は精神科病院に勤務する看護者を対象にした 横断面での調査デー夕を基に，統計的手法によって因 果関係を推定するという方法を採用している。したが って，その他の看護者集団を対象とした検討，あるい は縦断的な調査による検討等がさらに必要である. 今 後の研究課題とし, 得られた解答の一般化・普遍化を 探求していきたい.

\section{V. 結 論}

本研究において描かれた因果関係モデルから，次の ことが示唆された。

仕事量の多さや患者との関係に由来する負担感や葛 藤が続くと，バーンアウトの最初の現象である疲弊感 が生じる。この疲弊感は，シニシズム的態度というバ ーンアウトの次の現象を生む，患者に対する冷淡で無 関心な態度は患者関係にうまく対応できない看護者て 特にみられるが，職場の上司・同僚関係に悩んでいる 看護者もそのような態度に陥りやすくなると考えられ た．看護者のこのようなバーンアウト状態が医療事故 発生を導く．特に感情表出型のコーピングスタイルを とる看護者はバーンアウトに陥りやすく，医療事故発 生に繋がりやすい集団と考えられた。 
謝辞：調査にご協力いただきましたすべての皆さまに心よ り感謝申し上げます.

本研究は, 平成 14 年度 平成 15 年度科学研究費補助金 （基盤研究 C (2) 課題番号 14572238) 助成を受けて行いました. また, 本研究の一部は第 24 回日本看護科学学会学術集会に おいて発表しました。

\section{文献}

Cooper C. L., Baglioni A. J. (1988) : A structural model approach toward the development of a theory of the link between stress and mental health, Br. J. Med. Psychol., 61 (Pt1), 87-102.

Deary I. J., Blenkin H., Agius R. M., et al. (1996) : Models of job-related stress and personal achievement among consultant doctors, Br. J. Psychol., 87(Pt1), 3 -29 .

Endler N. S., Parker J. D. A. (1990) : Coping Inventory for Stressful Situations (CISS) ; Manual, Multi-Health Systems, Inc., Toronto.

古川壽亮, 鈴木ありさ, 斎藤由美, 他 1 名(1993)：CISS (Coping Inventory for Stressful Situations) 日本語版の 信頼性と妥当性; 対処行動の比較文化的研究への一寄与, 精神神経学雑誌, 95(8), 602-621.

東口和代, 森河裕子, 三浦克之, 他 3 名 (1998): 臨床看護職 者の仕事ストレッサーについて一仕事ストレッサー測定尺 度の開発と心理測定学的特性の検討一, 健康心理学研究, $11(1), 64-72$.

Hobfoll S. E. (1988) : The Ecology of Stress, Hemisphere, New York.

Hobfoll S. E. (1989) : Conservation of resources; A new attempt at conceptualizing stress, Am. Psychol., 44 (3), 513-524.

Hobfoll S. E., Freedy J. (1993) : Conservation of resources; A general stress theory applied to burnout. In W. B. Schaufeli, C. Maslach, T. Marek(Eds.), Professional Burnout; Recent Developments in Theory and Research, 115-129, Taylor \& Francis, Washington, DC.

川口貞親, 鵜川晃, 鈴木学美, 他 3 名(2004) : 看護師のメン タルヘルスと医療過誤，ヒヤリ・ハットの経験に関する横 断調査研究, 産業衛生学雑誌, 46 (Suppl.), 344.

Kitaoka-Higashiguchi K. (2005) : Burnout as a developmental process among Japanese nurses ; Investigation of Leiter's model, Japanese Journal of Nursing Science, 2(1), 9-16.

Kitaoka-Higashiguchi K., Nakagawa H. (2003 a) : Job strain, coping, and burnout among Japanese nurses, Japanese Journal of Health \& Human Ecology, 69 (3),
66-79.

Kitaoka-Higashiguchi K., Nakagawa H., Morikawa Y. et al. (2003 b) : Social support and individual styles of coping in the Japanese workplace; An occupational stress model by structural equation analysis, Stress and Health, 19(1), 37-43.

Kitaoka-Higashiguchi K., Nakagawa H., Morikawa Y., et al. (2004) : Construct validity of the Maslach Burnout Inventory-General Survey, Stress and Health, 20(5), 255-260.

北岡(東口)和代, 荻野佳代子, 増田真也(2004 a)：日本版 MBI-GS (Maslach Burnout Inventory-General Survey) の妥当性の検討, 心理学研究, 75(5), 415-419.

北岡 (東口)和代, 谷本千恵, 林みどり, 他 5 名 $(2004$ b) : 精 神科看護者のバーンアウトと職場ストレス要因についての 検討, 石川看護雑誌, 1(1)，7-12.

Leiter M. P. (1991) : Coping patterns as predictors of burnout ; The function of control and escapist coping, Journal of Organizational Behaviour, 12, 123-144.

Leiter M. P. (1993) : Burnout as a developmental process ; Consideration of models. In W. B. Schaufeli, C. Maslach, T. Marek (Eds.), Professional Burnout; Recent Developments in Theory and Research, 237250, Taylor \& Francis, Washington, DC.

Leiter M. P., Maslach C. (1988) : The impact of interpersonal environment on burnout and organizational commitment, Journal of Organizational Behavior, 9, 297-308.

正田亘 (2001)：ヒューマンエラーの原因と予防, 大山正, 丸 山康則 (編), ヒューマンエラーの心理学, 139-159, 麗澤 大学出版会, 千葉.

Maslach C., Jackson S. E., Leiter M. P. (1996) : Maslach Burnout Inventory Manual(3 rd ed.), Consulting Psychologists Press Inc., Palo Alto, CA.

Maslach C., Schaufeli W. B., Leiter M. P. (2001) : Job burnout, Ann. Rev. Psychol., 52, 397-422.

小田切優子, 大谷由美子, 下光輝一 (2004) : 大学病院の看護 職におけるインシデントとストレスに関する検討, 産業衛 生学雑誌, 46 (Suppl.), 341.

Revicki D. A., May H. J. (1985) : Occupational stress, social support, and depression, Health Psychology, 4 (1), 61-77.

佐々木恵, 山崎勝之 (2002)：コーピング尺度 (GCQ) 特性版の 作成および信頼性・妥当性の検討, 日本公衆衛生雑誌, 49(5), 399-408.

Stanton A. L., Danoff-Burg S., Cameron C. L., et al. (1994) : Coping through emotional approach; problems of conceptualization and confounding, J. Pers. Soc. Psychol., 66 (2), 350-362.

杉谷藤子 $(2000)$ ：「看護事故」防止の手引き，日本看護協会出 版会, 東京. 